\title{
Effects of Solar Heating for Control of Pink Root and Other Soil-borne Diseases of Onions
}

\author{
Chan-Jung Lee ${ }^{1 *}$, Jong-Tae Lee ${ }^{2}$, Jin-Seong Moon ${ }^{2}$, In-Jong Ha², Hee-Dae Kim², Woo-Il Kim² and \\ Mi-Geon Cheon ${ }^{3}$ \\ ${ }^{1}$ Division of Applied Microbiology, National Institute of Agricultural Science and Technology, RDA, Suwon 441-707, Korea \\ ${ }^{2}$ Onion Research Institute, Gyeongnam Agricultural Research and Extension Services, Changnyeong 635-821, Korea \\ ${ }^{3}$ Gyeongnam Agricultural Research and Extension Services, Jinju 660-370, Korea
}

(Received on May 25, 2007; Accepted on August 28, 2007)

These experiments were carried out to examine efficacy of soil solarization for control of pink root disease by means of mulching with transparent polyethylene sheets in the hot season. The effects of soil solarization on incidence of pink-root disease caused by Pyrenochaeta terrestris and on onion growth and on populations of soil fungi were investigated. Solarization was dramatically effective in reducing pink root incidence in onion seedling and harvested onion bulb. A 30-day and 40-day solarization treatment significantly improved seedling survival and increased yield of 'Changnyeongdeago' onion while decreasing incidence of pink root. Populations of soil fungi from fields planted to onion were assayed on selective media. Solarization treatment was effective in reducing populations of $P$. terrestris, Pythium spp., and Rhizoctonia sp. in soil. Increase of yield of onion bulbs was associated with control of soilborne pathogenic fungi. Soil solarization had beneficial effects on yield, bulb diameter, or incidence of pink root.

Keywords : Allium cepa, Pyrenochaeta terrestris, soil infestation, solarization, transplanting

Onion (Allium cepa) has been cultivated in large areas of the Korea and become one of the major vegetable crops. In Korea, its production has increased steadily from approximately 12.352 ha in 2003 to 15,309 ha in 2005 (KREI). Pink root disease, caused by Pyrenochaeta terrestris (Hansen) Gorentz, J. C. Walker and Larson (Gorenz et al., 1948; Hansen, 1929), is a serious soil-borne disease of onion throughout Korea. This disease was first reported to be caused by $P$. terrestris by Kim et al. (2003) in Korea.

The pathogen attacks the root system causing pink discoloration and root destruction, and may cause heavy damage to the crop, reducing both yield and quality (Katan et al., 1980; Vaughan and Siemer, 1971). Infected onion

\footnotetext{
*Corresponding author.

Phone) +82-31-290-0367, FAX) +82-31-290-0209

E-mail) bio0001@hanmail.net
}

roots are initially light pink in color, gradually turning deeper pink and finally dark purple as the disease progresses. As new roots are produced, they are infected, turn pink, and eventually die. If infection continues, plants become stunted and may appear to be suffering from drought or a nutrient deficiency, but usually do not die.

In addition, infection by $P$. terrestris can facilitate the entry of Fusarium spp., resulting in bulb rots (Davis and Henderson, 1973; Kreutzer, 1941). Soil-borne fungi isolated and identified from onion in Korea include Pythium irregulare, Rhizoctonia solani, Rhizoctonia spp., Fusarium spp., and Phoma terrestris. A new approach for controlling a variety of soil-borne pathogens and weeds by means of solar heating of the soil was developed in Israel (Katan et al., 1976). This is accomplished by covering moistened soil with transparent polyethylene sheets during the hot season. Consequently, the pathogens are weakened or killed (Katan, 1980). The method has also been adopted to pink root infection and expression (Katan et al., 1980; Rabinowitch et al., 1981). Solarization offers potential cost reduction over chemical fumigation without residue or toxicity problems.

In Korea, onions are directly seeded into seedbeds in August and September when soil temperatures $3 \mathrm{~cm}$ deep range from 20 to $30^{\circ} \mathrm{C}$, and seedlings are transplanted into fields in October and November when soil temperatures range from 10 to $20^{\circ} \mathrm{C}$. The initial pink root disease may have caused the infection of onion seedlings by the causal fungus in the seedbed. Therefore, the infection of onion seedlings before planting is often unavoidable. This study was undertaken to determine the incidence and severity of pink root on onion in Korea, and the influence of soil solarization in a seedbeds and fields naturally infested with P. terrestris.

\section{Materials and Methods}

Onion (Allium cepa) cultivar 'Changnyeongdeago' was used in the experiments, which were conducted in onion field established at the Onion Research Institute in 
Changnyeong, Gyeongnam. Experiments were carried out in the 2004 and 2005 production periods. This field had been planted to onion for 15 consecutive years, and was known to be severely infested with the pink root pathogen. Although the inoculum density was not quantified, levels were high enough to severely stunt and even kill susceptible onion cultivars in previous years. A randomized complete block design with three replications was used on each site. Each plot size was $5 \mathrm{~m}$ wide by $5 \mathrm{~m}$ long. The treatment consisted with non-solarized, 15 days, 30 days and 40 days solarized treatment. Soil solarization was accomplished by covering moistened soil with $20 \mu \mathrm{m}$ thick of transparent polyethylene sheets during the summer and control plots remained to be untreated. As the plastic was buried only in the furrows of the outside seedbeds, no soil disturbance occurred to the seedbeds when the plastic was removed. Soil temperatures were continuously recorded with thermocouples at depths of 5,10 and $20 \mathrm{~cm}$, using a micrologger (Thermo recorder TR-71U, Japan) from July 14 to August 23. Seeds of 'Changnyeongdeago' onion, a pink rootsusceptible cultivar, were directly seeded into seed beds (1.2 $\mathrm{m}$ wide and $20 \mathrm{~cm}$ high) on September 3 and seedlings are transplanted into each plot in November.

Before transplanting and harvesting for determination of disease incidence, fifty-five plants were selected at random from each plot and evaluated for the percentage of roots showing pink discoloration. Fifty were visually rated for the diagnostic discoloration on the basal plate and adjacent 4 $\mathrm{cm}$ of roots. The five remaining plants were assayed for $P$. terrestris infection by the method of Watson (1961). The diagnostic test was the development of pink pigmentation on sterilized wheat straw. Plants were prepared for assay by washing soil and debris from the roots, then excising the intact basal plate and $4 \mathrm{~cm}$ of root system. This material was surface-sterilized by a $10 \mathrm{sec}$ dip in $90 \%$ ethyl alcohol followed by $45 \mathrm{sec}$ in $0.5 \%$ sodium hypochlorite with a triple rinse in distilled autoclaved water. One intact root system per plate was used. Cultures were evaluated after 26 days of incubation at room temperature. The rating scale for pink root severity was 0 to 9 , with $0=$ no roots discolored, $1=\leq 20 \%$ of roots discolored, $3=20$ to $40 \%$ roots discolored, $5=40$ to $60 \%$ roots discolored, $7=60$ to $80 \%$ roots discolored and $9=>80 \%$ of roots discolored.

The soil at the seedbed was sampled before and after treatment and before transplanting. The samples were used in separate bioassays to determine the effect of treatment on the population density and distribution of $P$. terrestris. For bioassays of field soils, 10 cores of soil were sampled from $0-20 \mathrm{~cm}$ in each plot, mixed thoroughly and assayed for $R$. solani and Rhizoctonia spp. on a modified tannic-acid benomyl medium (Sumner and Bell, 1982) with a multiplepellet soil sampler (Henis et al., 1978), for Pythium spp. on pimaricin, ampicillin, rifampicin and PCNB medium (Jeffers and Martin, 1986), on modified PCNB medium for F. solani and total Fusarium spp. (Papavizas, 1967). P. terrestris was assayed on sterile cheesecloth in a medium prepared from $3 \mathrm{~g} \mathrm{NaNO}_{3}, 1 \mathrm{~g} \mathrm{MgSO}_{4} \cdot 7 \mathrm{H}_{2} \mathrm{O}, 0.5 \mathrm{~g}$ chloramphenicol, and $20 \mathrm{~g}$ agar in 1 liter of deionized water (Strobel and Lorbeer, 1990).

Fifty-five days after sowing, onion seedlings were transplanted with $20 \times 15 \mathrm{~cm}$ of planting distance in the same experimental field. Irrigation water was delivered when soil matric potential reached $-30 \mathrm{kPa}$, as measured by a tensiometer. A total of $77 \mathrm{~kg} \mathrm{P}_{2} \mathrm{O}_{5}, 154 \mathrm{~kg} \mathrm{~K}_{2} \mathrm{O}$ and $240 \mathrm{~kg}$ $\mathrm{N} / \mathrm{ha}$ was applied throughout the growth season on cultivar 'Changnyeongdeago'. Five applications of chlorothalonil and spinosad were applied for insect and disease control, respectively. Bulbs were harvested on June 5, 2005. More than $80 \%$ of plant tops had fallen over in all plots at harvest, indicating that the onions were mature.

\section{Results and Discussion}

Solarization increased soil temperature in covered plots to a depth of at least $20 \mathrm{~cm}$ at the interval July 14 - August 23, the hottest period in 2004 (Table 1). The maximum temperature in solarized plots reached $56.5^{\circ} \mathrm{C}$ at $5 \mathrm{~cm}$, $11.5^{\circ} \mathrm{C}$ higher than that of untreated soil at the same depth. The average maximum soil temperature in solarized plots was $11.3,6.0$ and $3.6^{\circ} \mathrm{C}$ higher at 5,10 and $20 \mathrm{~cm}$ depths, respectively, compared with those of untreated soils. The polyethylene film maintained high soil moisture in solarized plots, whereas considerable drying took place in untreated soil plots after the initial irrigation, allowing surface temperatures to rise.

Considerably high soil temperatures were generated in solarized field plots in 2004. This was due to a largercovered plot and hotter clear weather during the solarization period. Cumulative hours between $50^{\circ} \mathrm{C}$ to $55^{\circ} \mathrm{C}$ at 5 $\mathrm{cm}$ depth were 74 , while those at between from $45^{\circ} \mathrm{C} 50^{\circ} \mathrm{C}$ at $10 \mathrm{~cm}$ depth were 73 (Table 2). Cumulative hours of soil temperature above $40^{\circ} \mathrm{C}$ at $20 \mathrm{~cm}$ depth were increased by

Table 1. Effect of solarization on soil temperatures during treatment in July-August 2004

\begin{tabular}{cccccccc}
\hline \hline \multirow{2}{*}{$\begin{array}{c}\text { Depth } \\
(\mathrm{cm})\end{array}$} & \multicolumn{4}{c}{ Solarization } & & \multicolumn{3}{c}{ Control } \\
\cline { 2 - 4 } \cline { 7 - 9 } & $\begin{array}{c}\text { Max. } \\
\text { (avge) }\end{array}$ & $\begin{array}{c}\text { Min. } \\
\text { (avge) }\end{array}$ & $\begin{array}{c}\text { Range } \\
\text { (max.) }\end{array}$ & & $\begin{array}{c}\text { Max. } \\
\text { (avge) }\end{array}$ & $\begin{array}{c}\text { Min. } \\
\text { (avge) }\end{array}$ & $\begin{array}{c}\text { Range } \\
\text { (max) }\end{array}$ \\
\hline 5 & 51.5 & 20.4 & $25.1-56.5$ & & 40.2 & 18.7 & $22.6-45.0$ \\
10 & 42.7 & 22.1 & $27.1-48.4$ & & 36.7 & 19.4 & $23.3-39.9$ \\
20 & 34.5 & 24.3 & $28.3-39.0$ & 30.9 & 19.9 & $24.8-33.7$ \\
\hline
\end{tabular}


Table 2. Cumulative heat exposure of solarized and non solarized soil profiles in July-Agust 2004

\begin{tabular}{|c|c|c|c|c|c|c|c|c|c|c|c|}
\hline \multirow{3}{*}{$\begin{array}{c}\text { Depth } \\
\text { (cm) }\end{array}$} & \multicolumn{11}{|c|}{ Cumulative hours of Soil temperatures(hr) } \\
\hline & \multicolumn{6}{|c|}{ Solarized } & \multicolumn{5}{|c|}{ Not solarized } \\
\hline & $25-30^{\circ} \mathrm{C}$ & $30-35^{\circ} \mathrm{C}$ & $35-40^{\circ} \mathrm{C}$ & $40-45^{\circ} \mathrm{C}$ & $45-50^{\circ} \mathrm{C}$ & $50-55^{\circ} \mathrm{C}$ & $20-25^{\circ} \mathrm{C}$ & $25-30^{\circ} \mathrm{C}$ & $30-35^{\circ} \mathrm{C}$ & $35-40^{\circ} \mathrm{C}$ & $40-45^{\circ} \mathrm{C}$ \\
\hline 5 & 141 & 326 & 194 & 128 & 97 & 74 & 46 & 381 & 301 & 170 & 62 \\
\hline 10 & 72 & 259 & 369 & 187 & 73 & - & 15 & 385 & 458 & 102 & - \\
\hline 20 & 67 & 230 & 631 & 32 & - & - & 7 & 269 & 684 & - & - \\
\hline
\end{tabular}

Table 3. Populations of fungi in soil and comparisons of interest in an onion field in 2004

\begin{tabular}{|c|c|c|c|c|c|c|c|c|c|}
\hline \multirow{2}{*}{$\begin{array}{l}\text { solarized period } \\
\text { (day) }\end{array}$} & \multicolumn{3}{|c|}{ P. terrestris (CFU/g) ${ }^{z, y}$} & \multicolumn{3}{|c|}{ Pythium sp. $(\mathrm{CFU} / \mathrm{g})^{\mathrm{z}, y}$} & \multicolumn{3}{|c|}{ Rhizoctonia solani $(\mathrm{CFU} / 100 \mathrm{~g})^{z, x}$} \\
\hline & 10 Jul. & 25 Aug. & 3 Nom. & $10 \mathrm{Jul}$. & 25 Aug. & 3 Nom. & $10 \mathrm{Jul}$. & 25 Aug. & 3 Nom. \\
\hline Untreated & $17 \mathrm{a}$ & $16 \mathrm{~b}$ & $20 \mathrm{~b}$ & $25 \mathrm{a}$ & $26 b$ & $35 \mathrm{c}$ & $12 \mathrm{a}$ & $11 b$ & $15 b$ \\
\hline 15 & $15 \mathrm{a}$ & $2 \mathrm{a}$ & $3 a$ & $23 a$ & $5 a$ & $12 b$ & $11 \mathrm{a}$ & $1 \mathbf{a}$ & $5 a$ \\
\hline 30 & $16 \mathrm{a}$ & $0 \mathrm{a}$ & la & $28 \mathrm{a}$ & $3 \mathrm{a}$ & $5 \mathrm{a}$ & $12 \mathrm{a}$ & $0 \mathrm{a}$ & $2 a$ \\
\hline 40 & $14 \mathrm{a}$ & $0 \mathrm{a}$ & $0 \mathrm{a}$ & $25 \mathrm{a}$ & la & $4 a$ & $13 \mathrm{a}$ & $0 \mathrm{a}$ & $1 \mathrm{a}$ \\
\hline
\end{tabular}

${ }^{2}$ Means followed by the same letter within columns do not differ significantly (Duncan's multiple range test, $P=0.05$ )

Soil was solarized on July 14, 2004.

${ }^{\mathrm{y}} \mathrm{CFU} / \mathrm{g}$; colonies forming on selective media per gram of soil.

${ }^{\mathrm{x}} \mathrm{CFU} / \mathrm{g}$; colonies forming on selective media per $100 \mathrm{~g}$ of soil.

Table 4. Effect of soil solarization on disease of onion seedlings naturally infested with P. terrestris in July-August 2004

\begin{tabular}{cccccc}
\hline $\begin{array}{c}\text { solarized period } \\
(\text { day })\end{array}$ & $\begin{array}{c}\text { No. of } \\
\text { leaves }\end{array}$ & $\begin{array}{c}\text { Longest leaf length } \\
(\mathrm{cm})^{z}\end{array}$ & $\begin{array}{c}\text { Pink root incidence } \\
(\% \text { of plant })^{z, y}\end{array}$ & $\begin{array}{c}\text { Pink root } \\
\text { severity }\end{array}$ & $\begin{array}{c}\text { damping-off disease } \\
(\% \text { of plant })^{z}\end{array}$ \\
\hline Untreated & $4.5 \mathrm{a}$ & $33.6 \mathrm{~b}$ & $99.5 \mathrm{c}$ & $9.0 \mathrm{~b}$ & $20.0 \mathrm{~b}$ \\
15 & $4.4 \mathrm{a}$ & $40.1 \mathrm{a}$ & $8.5 \mathrm{~b}$ & $0.7 \mathrm{a}$ & $4.5 \mathrm{a}$ \\
30 & $4.2 \mathrm{a}$ & $40.8 \mathrm{a}$ & $3.5 \mathrm{a}$ & $0.2 \mathrm{a}$ & $1.7 \mathrm{a}$ \\
40 & $4.7 \mathrm{a}$ & $40.7 \mathrm{a}$ & $0.5 \mathrm{a}$ & $0.2 \mathrm{a}$ & $1.3 \mathrm{a}$ \\
\hline
\end{tabular}

${ }^{z}$ Means followed by the same letter within columns do not differ significantly (Duncan's multiple range test, $P=0.05$ )

${ }^{y}$ Percentage of plants exhibiting root discoloration.

${ }^{\times}$Visual rating of plants; $0=$ no roots discolored, $1=<20 \%, 3=20$ to $40,5=40$ to $60,7=60$ to $80,9=>80 \%$ of roots discolored.

solinization. Untreated soil temperature at $5 \mathrm{~cm}$ also reached high levels by drying after the initial irrigation, but the rest of the profile remained at moderate temperatures throughout the treated period.

Soil solarization reduced populations of $P$. terrestris, Pythium sp., and Rhizoctonia sp. in soil of seedbed in August (Table 3). The plots treated with 30-day and 40-day were the most effective in reducing populations of soil fungi and 15-day were less effective, compared with no solarization (Table 3). The temperature and time exposure in 2004 was sufficient to project substantial control of many soil-borne pathogen based on previous reports (Martyn and Hartz, 1986; Pullman et al., 1981b). Pullman et al. (1981a) determined laboratory thermal death curves for Thielaviopsis basicola, Rhizoctonia solani, Pythium ultimum, and Verticillium dahliae, demonstrating $90 \%$ control with exposure to $42^{\circ} \mathrm{C}$ for $45 \mathrm{hr}$ or less, depending on species. Solarization was clearly effective in reducing pink root incidence and expression in onion seedling (Katan et al., 1980). Nearly all plants in untreated plots of cultivars exhibited some degree of root discoloration, while pink root incidence in 30 days solarized plots was less than $5 \%$ and disease severity index in solarized plots was less than 1 (Table 4). Plant growths were found to be reduced in non-solarized soil as compared to plants grown in solarized soil. There were no significant differences among treatments in leaf number but was a significant increase in leaf length (Table 4).

Solarization significantly improved stand establishment. Substantial damping-off was $20 \%$ in untreated plots but was $<5 \%$ in solarized plots (Table 4 ). The pathogens involved in damping-off were mostly identified as Rhizoctonia solani (data not shown). Solarization of the onion seedbeds dramatically decreased disease incidence in transplants, but did not confer lasting benefit on those transplants when grown to maturity in treated plots. Improvement in stand establishment by solarized method of soil disinfestations corroborated previous reports of pink root influences on onion stands (Katan et al., 1980; Lacy and Roberts, 1982; 
Table 5. Effect of soil solarization on disease and growth of onion naturally infested with $P$. terrestris in 2004-2005

\begin{tabular}{cccccc}
\hline \hline $\begin{array}{c}\text { solarized period } \\
\text { (day) }\end{array}$ & $\begin{array}{c}\text { Bulb diam. } \\
(\mathrm{mm})\end{array}$ & $\begin{array}{c}\text { Bulb heig. } \\
(\mathrm{mm})\end{array}$ & $\begin{array}{c}\text { Bulb } \\
(\mathrm{g})\end{array}$ & $\begin{array}{c}\text { Pink root incidence } \\
(\% \text { of plant })^{2, \mathrm{y}}\end{array}$ & $\begin{array}{c}\text { Pink root } \\
\text { severity }\end{array}$ \\
\hline Untreated & $63.8 \mathrm{~b}$ & $66.5 \mathrm{~b}$ & $111 \mathrm{c}$ & $99.9 \mathrm{c}$ & $9.0 \mathrm{c}$ \\
15 & $65.6 \mathrm{~b}$ & $64.2 \mathrm{~b}$ & $131 \mathrm{~b}$ & $60.9 \mathrm{~b}$ & $3.5 \mathrm{~b}$ \\
30 & $71.8 \mathrm{a}$ & $77.4 \mathrm{a}$ & $168 \mathrm{a}$ & $9.5 \mathrm{a}$ & $1.4 \mathrm{a}$ \\
40 & $72.4 \mathrm{a}$ & $76.6 \mathrm{a}$ & $172 \mathrm{a}$ & $5.2 \mathrm{a}$ & $1.2 \mathrm{a}$ \\
\hline
\end{tabular}

${ }^{7}$ Means followed by the same letter within columns do not differ significantly (Duncan's multiple range test, $P=0.05$ )

'Percentage of plants exhibiting root discoloration.

${ }^{\times}$Visual rating of plants; $0=$ no roots discolored, $1=<20 \%, 3=20$ to $40,5=40$ to $60,7=60$ to $80,9=>80 \%$ of roots discolored.

Rabinowith et al., 1981).

Solarization reduced pink root expression dramatically in the field plots (Table 5). Before harvesting, the rate of diseased plants in the untreated plots reached nearly $100 \%$, while at the same time less than $10 \%$ expressed symptoms in the 30-days solarized plots and disease severity index was $<2$ (Table 5). Obvious differences in growth existed, with plants in solarized plots being larger and exhibiting less leaf tip burn. Onion growths in solarized plots were superior to untreated plots with respect to bulb diameter and weight, but no significant difference was shown between 30-day and 40-day solarized treatment in 2005. Solarization increased mean bulb weight to $151 \%$ and $155 \%$, respectively, as compared to that of bulbs in untreated plots (Table 5). The excellent control of $P$. terrestris by solarization was attributed to the considerably higher soil temperatures. Solarization of larger plots may yield even better results because of even higher temperatures due to a further reduction in edge effects. Vauhan and Siemer (1971) reported that seedbed treatment effects would have been evident if the transplants had been subsequently planted into a noninfested field soil (Katan et al., 1980; Rabinowitch et al., 1981). Soil solarization has been used effectively to reduce populations of soilborne pathogens, including $P$. terrestris, in Israel (Katan et al., 1980) and Australia (Porter et al., 1989). Although soil solarization has been successfully for control of pink root disease, there was hardly known about the proper solarization periods for control of pink root disease. Accordingly, we concluded that solarization periods of 30 days or more is appropriate for effective disease control, healthy growth of onion and higher yields as well.

\section{References}

Davis, G. N. and Henderson, W. J. 1937. The interrelation of the pathogenicity of a Phoma and a Fusarium on onions. Phytopathology 27:763-772.

Hansen, H. N. 1929. Etiology of the pink-root disease of onions. Phytopathology 19:691-704.

Gorenz, A. M., Walker, J. C. and Larson, R. H. 1948. Morphology and taxonomy of the onion pink root fungus. Phytopathology
38:831-840.

Henis, Y., Ghaffar, A., Baker, R. and Gillespie, S. L. 1978. A new pellet soil-sampler and its use for the study of population dynamics of Rhizoctonia solani in soil. Phytopathology 68:371-376.

Jeffers, S. N. and Martin, S. B. 1986. Comparison of two media selective for Phytophthora and Pythium species. Plant Dis. 70:1038-1043.

Katan, J. 1980. Solar pasteurization of soils for disease control: status and prospects. Plant Dis. 64:450-454.

Katan, J., Greenberger, A., Alon, H. and Grinstein, A. 1976. Solar heating by polyethylene mulching for the control of diseases by soilborne pathogens. Phytopathology 76:683-688.

Katan, J., Rotem, I., Finkel, Y. and Daniel, J. 1980. Solar heating of the soil for the control of pink root and other soilborne diseases on onions. Phytoparasitica 8:39-50.

Kim, Y. K., Lee, S. B., Shim, H. S., Lee, C. J. and Kim, H. D. 2003. Pink root of onion caused by Pyrenochaeta terrestris (syn. Phoma trrestris). Kor. J. Plant Pathol. 19:195-199.

Korea Rural Economic Institute (KREI). 2005. The Prospect of agriculture. pp. 411-426.

Kreutzer, W. A. 1941. Host-parasite relationships in pink root of Allium cepa: II. The action of Phoma terrestris on Allium cepa and other hosts. Phytopathology 31:907-915.

Lacy, M. L. and Roberts, D. L. 1982. Yields of onion cultivars in Midwestern organic soils infested woth Fusarium oxsporum $\mathrm{f}$. sp. Cepae and Pyrenochaeta terrestris. Plant Dis. 66:10031006.

Martyn, R. D. and Hartz, T. K. 1986. Use of soil solarization to control Fusarium wilt of watermelon. Plant Dis. 70:762-766.

Papavizas, G. G. 1967. Evaluation of various media and antimicrobial agents for isolation of Fusarium from soil. Phytopathology 57:848-852.

Porter, I. J., Merriman, P. R. and Keane, P. T. 1989. Integrated control of pink root (Pyrenochaeta terrestris) of onions by dazomet and soil solarization. Aust. J. Agric. Res. 40:861-869.

Pullman, G. S., DeVay, J. E. and Garber, R. H. 1981a. Soil solarization and thermal death: A logarithmic relationship between time and temperature for four soil-borne plant pathogens. Phytopathology 71:959-964.

Pullman, G. S., DeVay, J. E., Garber, R. H. and Weinhold, A. R. 1981b. Soil solarization: Effects of Verticillium wilt cotton and soil-borne populations of Verticillium dahliae, Pythium spp., Rhizoctonia solani and Thielaviopsis basicola. Phytopa- 
thology 71:959-964.

Punithalingam, F. and Holliday, P. 1973. Pyrenochaeta terrestris. CMI descriptions of pathogenic fungi and bacteria. No. 397, CMI, Kew, England.

Rabinowitch, H. K., Katan, J. and Rotem, I. 1981. The response of onions to solar heating, agricultural practices and pink-root disease. Scientia Hort. 15:331-340.

Sneh, B., Netzer, D. and Krikun, J. 1974. Isolation and identification of Pyrenochaeta terrestris from soil on dilution plates. Phytopathology 64:275-276.
Strobel, N. E. and Lorbeer, J. W. 1990. A novel differential medium for the quantification of Phoma terrestris in organic soils. (Abstr.) Phytopathology 80:1008.

Sumner, D. R. and Bell, D. K. 1982. Root diseases of corn induced by Rhizoctonia solani and Rhizoctonia zeae. Phytopathology 72:86-91.

Vauhan, E. K. and Siemer, S. R. 1971. Soil fumigation for onion pink root. Down to Earth 26:1-4.

Watson, R. D. 1961. Rapid identification of the onion pink root fungus. Plant Dis. Rptr. 45:289. 